\title{
Brush Seal Performance and Durability Issues Based on T-700 Engine Test Results
}

\author{
R. C. HENDRICKS \\ National Aeronautics and Space Administration, Lewis Research Center, Cleveland, $\mathrm{OH} 44135$
}

\begin{abstract}
The integrity and performance of brush seals have been established. Severe bench and engine tests have shown high initial wear or rub-in rates, material smearing at the interface, and bristle and rub-runner wear, but the brush seals did not fail. Short-duration ( $46 \mathrm{hr}$ ) experimental T-700 engine testing of the compressor discharge seal established over 1-percent engine performance gain (brush versus labyrinth). Long-term gains were established only as leakage comparisons, with the brush at least 20 percent better at controlling leakage. Long-term materials issues, such as wear and ultimately seal life, remain to be resolved. Future needs are cited for materials and analysis tools that account for heat generation, thermomechanical behavior, and tribological pairing to enable original equipment manufacturers to design high-temperature, high-surface-speed seals with confidence.
\end{abstract}

Key Words: Seals; Brush seals; Turbojet; Tribology; Turbomachine; Coatings

$\mathbf{L}$ abyrinth seals are efficient, are readily integrated into designs as described by Trutnovsky [1977] and Stocker et al. [1977], and are generally easy to install into engines but are inherently unstable (Hendricks et al. [1992]). Although installing a simple swirl brake at the inlet significantly enhances the stability margin of labyrinth seals (Childs et al. [1989]), both static and dynamic brush seal systems have recently received considerable attention for turbomachine applications (Ferguson [1988]; Chupp and Nelson [1990]; Chupp and Dowler [1991]; Holle and Krishnan [1990]; Flower [1990]; Carlile et al. [1992]; Hendricks et al. [1992]). Brush seal systems are efficient, stable contact seals (Conner and Childs [1992]) that are often interchangeable with labyrinth seals but require a smooth rub-runner interface. Design issues are being addressed (Basu et al.[1993]; Braun et al. [1990]; Braun and Kudriavtsev [1993]; Hendricks et al. [1991]); current issues are centered on performance and durability or seal life as related to interface tribology.

\section{PERFORMANCE}

In a rather harsh test at low surface speeds, brush seals were subjected to hard rubs by engaging the bristles into a 40-gear-tooth rotor (Fig. 1). The bristles withstood over $1 \times 10^{9}$ cycles without pullout, fracture, or massive debris generation. Under conditions of severe rotor-stator interface damage, the seal leakage performance degraded some 30 percent, but the brush seal did not fail (Hendricks et al. [1993a]).

Testing of a brush seal between two honeycomblabyrinth shroud seals (Figs. 2 and 3 ) in the fourth-stage turbine of a T-700 experimental engine revealed the following (Hendricks et al. [1993b]):

1. Properly designed brush seals have sufficient integrity to withstand highly irregular surface operations at speeds to $335 \mathrm{~m} / \mathrm{s}(1,100 \mathrm{ft} / \mathrm{s})$ and shroud temperatures to $620^{\circ} \mathrm{C}\left(1,150^{\circ} \mathrm{F}\right)$ with a noncentered turbine orbit during steady and cyclic loading.

2. Upon initial start-up, bristle debris can be expected when installations are blind and surfaces are disjointed (e.g., shrouded blades).

3. Brush wear was estimated to be line to line with the maximum rotor orbit.

4. Installed torques can be high, but rub-in torques are low. In this case rotor reversals are not permitted.

5. The sacrificial elements were the Haynes 25 brush bristles; the René 80 turbine blades evidenced minor polishing. 


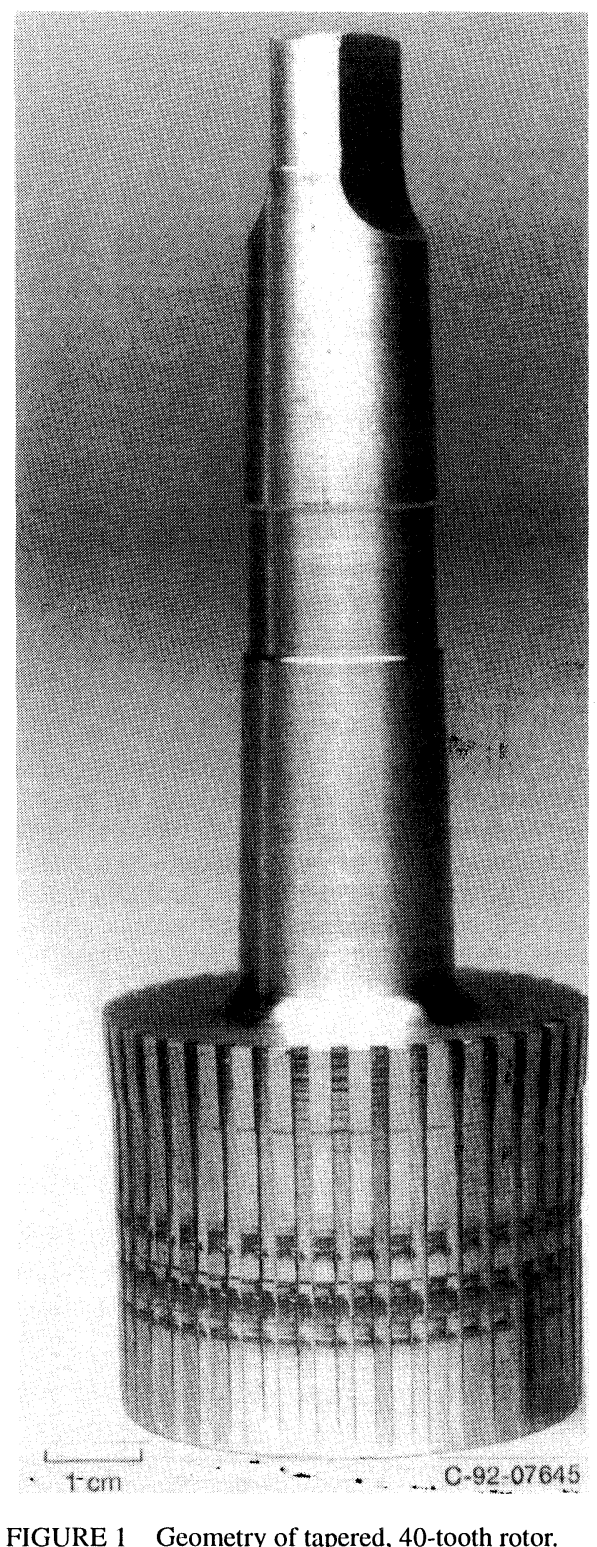

FIGURE 1 Geometry of tapered, 40-tooth rotor.

6. Pressure drop across the brush was small and performance changes were inconclusive.

The relative performance of a labyrinth and a dual-brush compressor discharge seal in a later T-700 experimental engine test provided conclusive evidence of a performance gain (Hendricks et al. [1994]). The labyrinth and dualbrush seal configurations are illustrated in Figs. 4 and 5, respectively. The seal had a nominal diameter of $71 \mathrm{~mm}$ ( $2.8 \mathrm{in}$.) and was tested for $46 \mathrm{hr}$ of engine operations. Test conditions included compressor discharge pressures to $1 \mathrm{MPa}(145 \mathrm{psi})$, temperature to $407^{\circ} \mathrm{C}\left(765^{\circ} \mathrm{F}\right)$, and operating speeds to $160 \mathrm{~m} / \mathrm{s}(530 \mathrm{ft} / \mathrm{s})$, with the working fluid being normally dry ambient air. To within the uncertainty of the data and short engine hours ( $46 \mathrm{hr}$ ), experimental engine specific fuel consumption for the brush seal was reduced over 1 percent relative to the labyrinth seal performance (Fig. 6). These high gains in performance may be partially lost as the brush wears line to line within the rotordynamic and static eccentricity envelope. Nevertheless, brush seals are anticipated to be at least 20 percent more efficient than labyrinth seals over the life of a commercial engine (Anon. [1993]).

Static applications of brush seals to the interface between the combustor and the compressor are under consideration as are fairings for external aircraft mountings (e.g., L-1011/Pegasus XL, Anon. [1994]).

\section{DURABILITY}

It is important that the seal perform as predicted. Historically, both labyrinth and brush seals, through improper design or installation, have caused shaft failures through excessive rubbing contact at their respective interfaces. Excessive eccentric shaft motion, thermomechanical changes in the rotor or seal configuration, and tribological pairing of the interface materials must be considered.

Derby and England [1992] reported minimal brush and coating wear using the Triboglide coating and a solidsolution-strengthened, nickel-chromium-aluminumbased superalloy bristle. The interface develops a tenacious chromia $\left(\mathrm{Cr}_{2} \mathrm{O}_{3}\right)$ and alumina $\left(\mathrm{Al}_{2} \mathrm{O}_{3}\right)$, yttriamodified oxide layer. Triboglide is a chromium carbide (CrC) containing a total of $12 \mathrm{wt} \%$ barium fluoride and calcium fluoride solid lubricants. Triboglide is based on the work of Harold Sliney at NASA Lewis Research Center but has no silver additive. The tests were performed with $1,200^{\circ} \mathrm{F}\left(650^{\circ} \mathrm{C}\right)$ air.

Atkinson and Bristol [1992] reported less wear for a cobalt-based alloy rubbing against $\mathrm{CrC}$ at room temperature than for a nickel-based alloy but nearly equivalent wear for either alloy at $480^{\circ} \mathrm{C}\left(900^{\circ} \mathrm{F}\right)$. However, the cobalt alloy/CrC combination proved to leak less under dynamic conditions and wear less at room temperature. The tests were conducted to simulate a CT7-9 compressor discharge seal. The brush was $5.08 \mathrm{in}$. $(129 \mathrm{~mm})$ in diameter and of standard Cross Mfg. construction.

The low-speed, hard-rub test results (Hendricks et al. [1993a]) showed stainless steel rotor grooving by the Haynes 25 bristles that was $0.076 \mathrm{~mm}$ (0.003 in.) in depth (Fig. 7) with erratic "whipped" leading-edge surfaces followed by convergent grooving to a clean-cut trailing edge (Fig. 8). Bristle losses were even more significant, up to $0.2 \mathrm{~mm}$ (0.008 in.). The generated debris was a fine black 


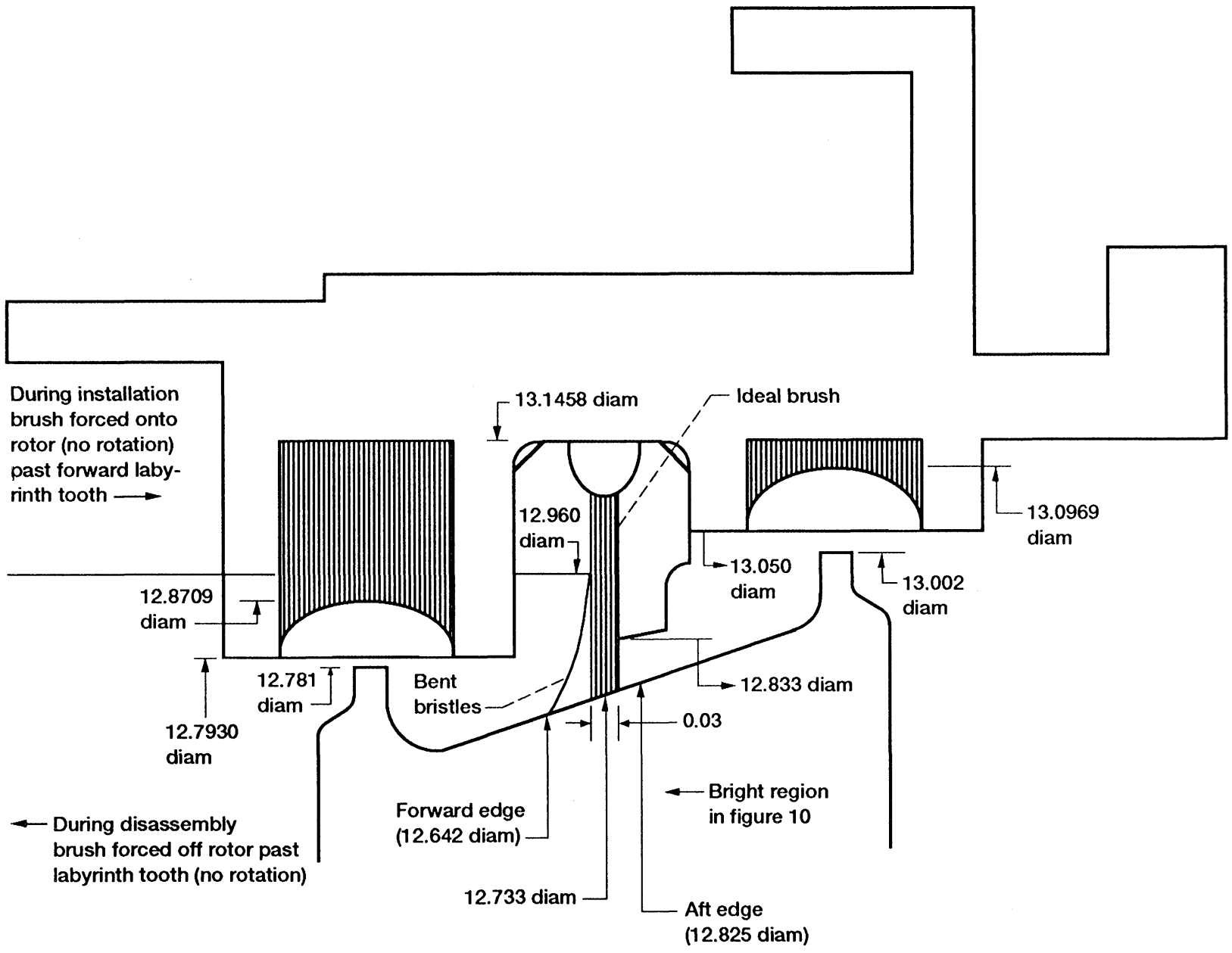

FIGURE 2 Cross-sectional view of split-ring brush seal configuration. (Brush design with $\sim 0.020$ in. interference; dimensions are in inches.)

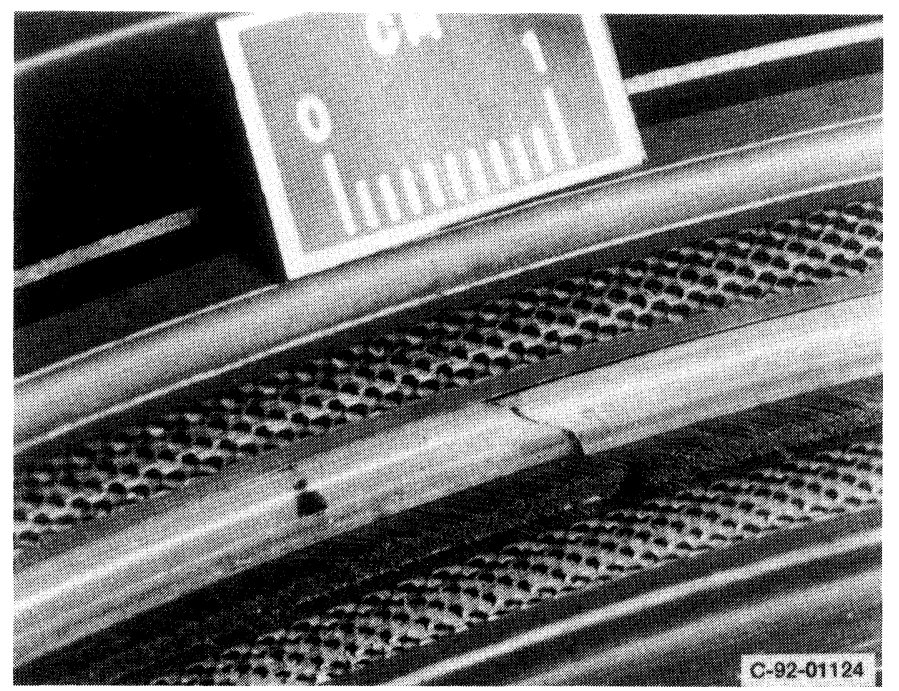

FIGURE 3 View of installed brush seal. a) Labyrinth seal package and airflow; b) Schematic of labyrinth compressor discharge seal. (Seal teeth and axis established by diameters A and B to be concentric within 0.003 full indicator reading. No steps allowed on tooth face or at fillet radius. All dimensions are in inches.) 

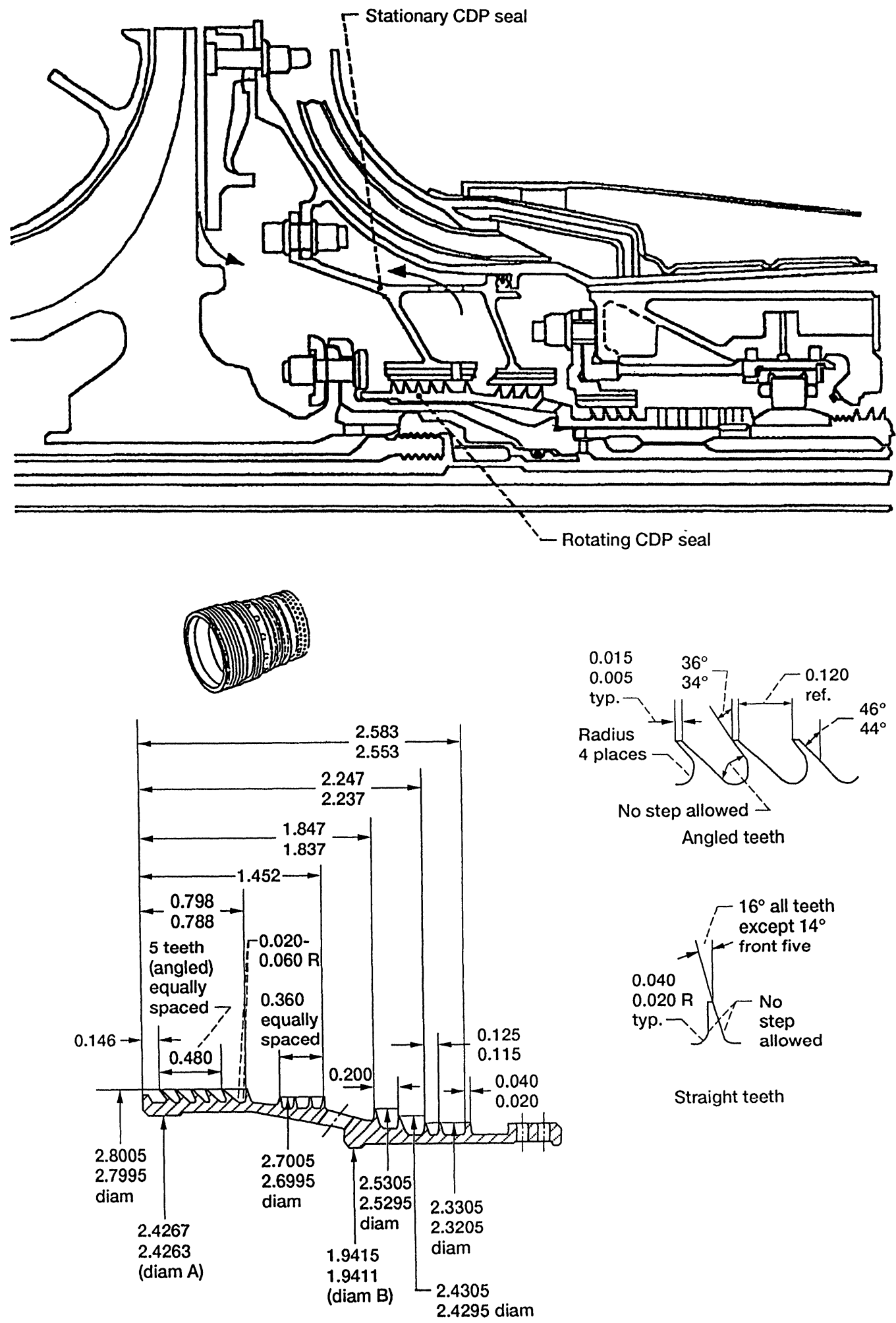

FIGURE 4 Labyrinth compressor discharge seal system. a) Brush seal package and airflow; b) Illustration of dual-brush compressor discharge seal system. 

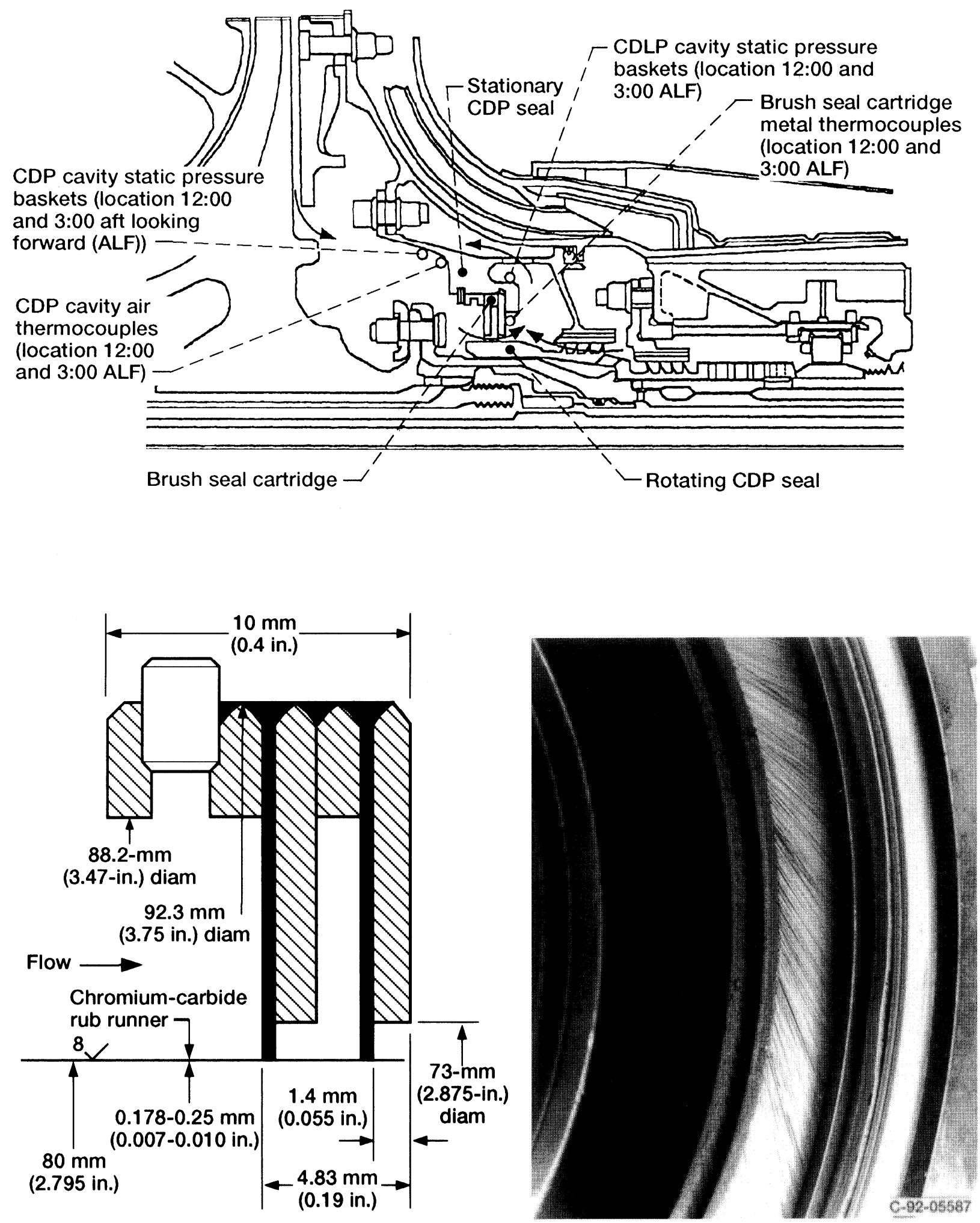

FIGURE 5 Dual-brush compressor discharge seal system and schematic of airflow. 


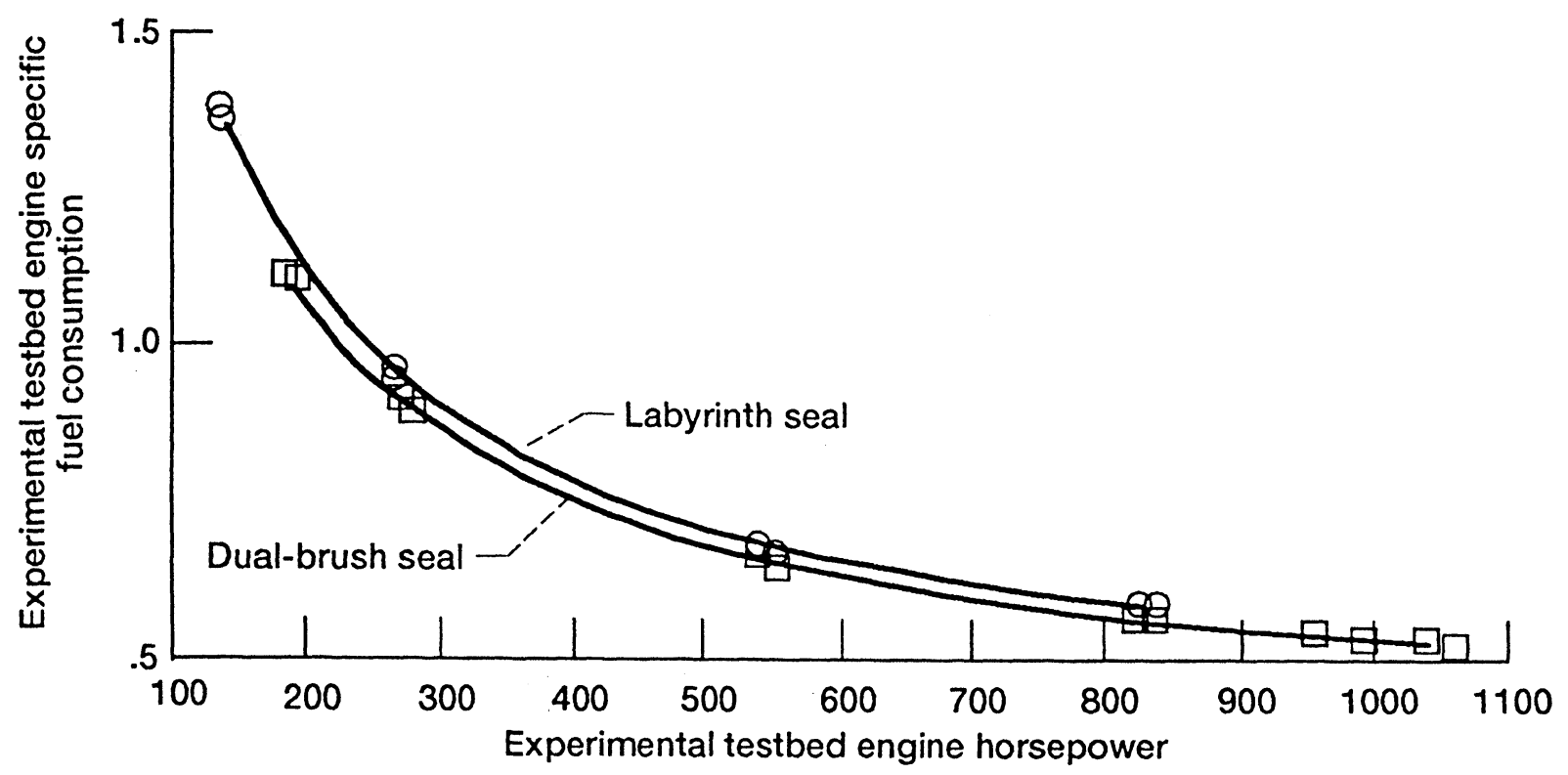

FIGURE 6 Experimental testbed engine specific fuel consumption as a function of horsepower. a) Leading edge; b) Midsection; c) Trailing edge.

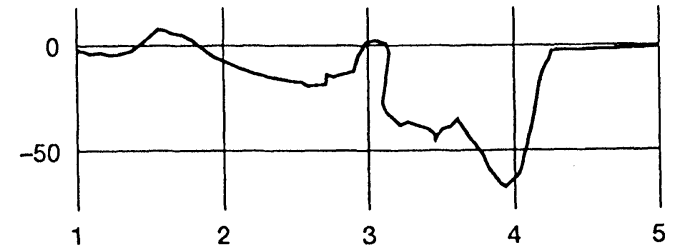

(c) Trailing edge.

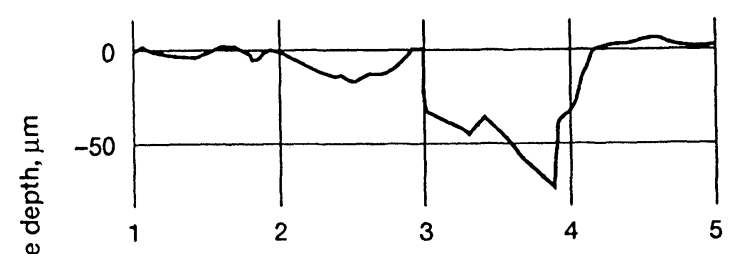

(b) Midsection.

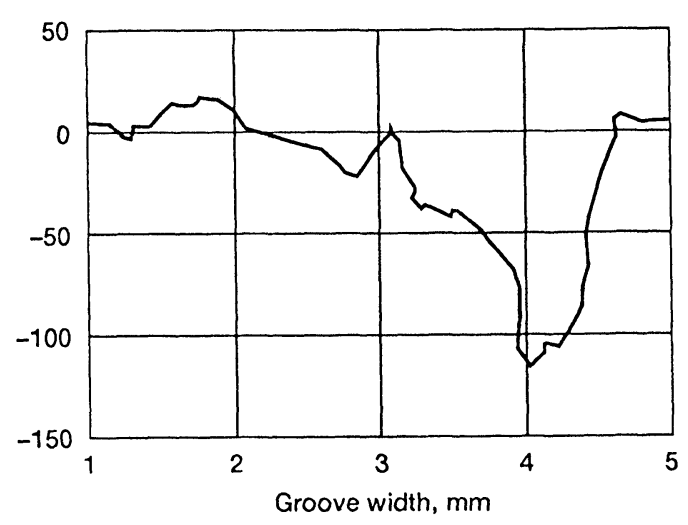

(a) Leading edge.

FIGURE 7 Profilometer traces for 40 -tooth rotor.

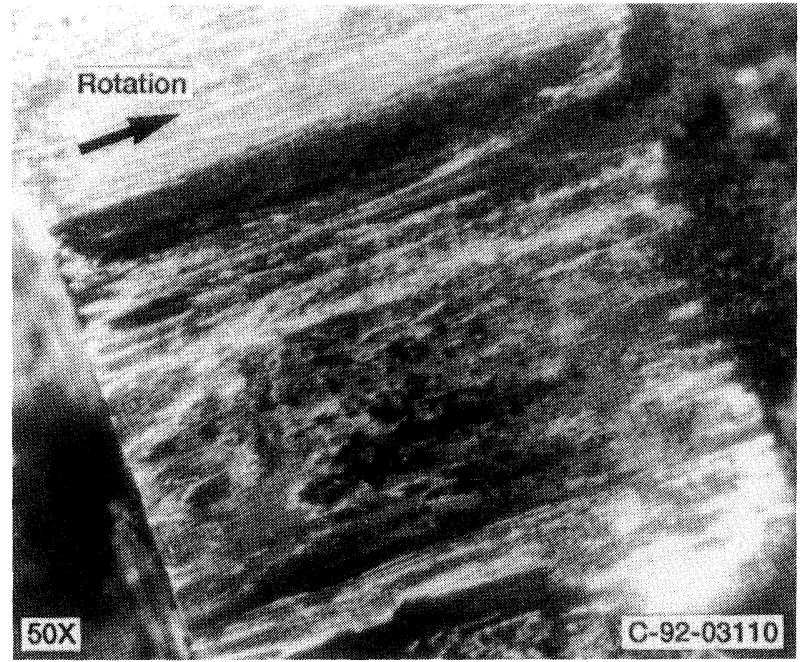

FIGURE 8 Rotor land with debris and rub scars (40-tooth rotor).

powder and rust-colored materials. The black powder appeared to be amorphous, but the rust-colored materials were magnetic and iron-rich, implying $\mathrm{Fe}_{3} \mathrm{O}_{2}$. Such fines could lodge within the brush, disrupting flexure characteristics and thermal heat sinking and ultimately rendering the brush incapable of sealing.

The integrity testing of a brush seal in a T-700 experimental engine (Hendricks et al. [1993b]) (Figs. 2 and 3) let to bristle clipping, excessive shear smearing of bristle material at the interface, and irregular bristle wear patterns (Fig. 9). Wear was assumed to be initially rapid, 


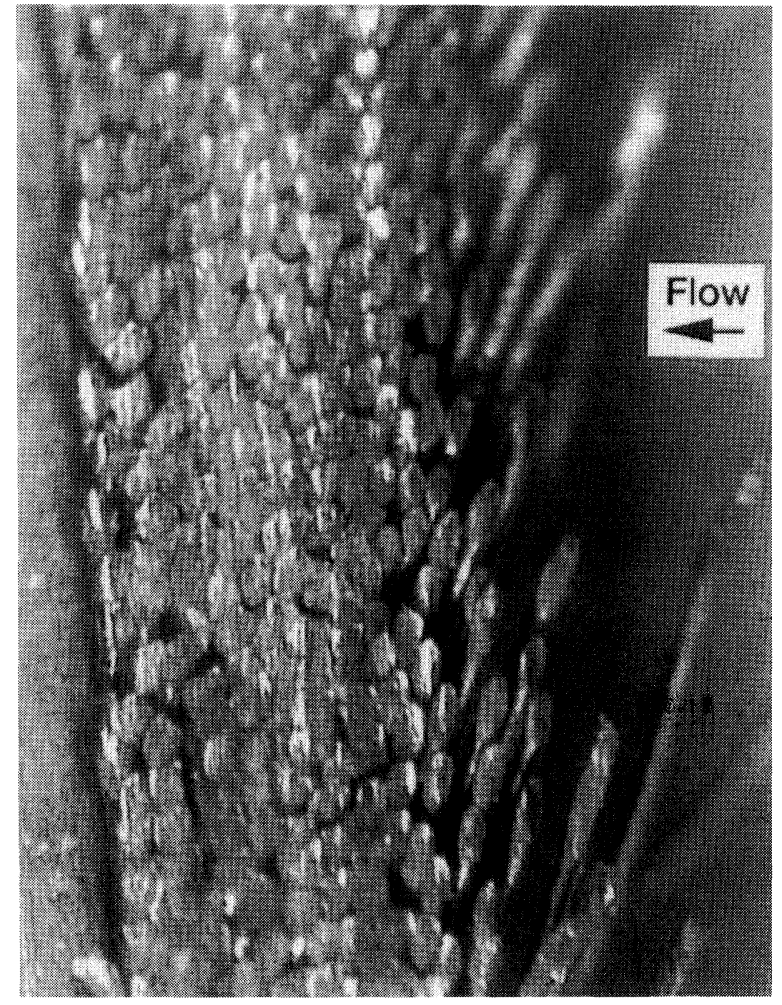

FIGURE 9 Details of brush seal wear pattern from T-700 fourth-stage turbine test.

then steady, and subsequently decreasing with time of engine operation. Cyclic operations cause more rapid wear because excessive bristle debris forms upon initial engine start-up. As anticipated, little material transfer or wear was noted on the fourth-stage turbine rotor, but the high points of the blade joints were polished (Fig. 10). The Haynes 25 bristles were sacrificed to the hard René 80 of rotor, leading to the loss of brush performance while maintaining the integrity of the fourth-stage turbine; this is very important. One metallographic sample of bristle cut from the brush wear track showed material smearing and a potential redistribution of the tungsten (Fig. 11). Such a nonuniformity of tungsten could indicate bristle melting at the interface. Multiple polished micrographs showed bristle tip distortions but no redistribution of the tungsten to within $1 \mu \mathrm{m}$ of the interface (Fig. 12). Even though the surface speeds and loads were high enough to produce a melt, melting is questionable; however, shear smearing (forming mudflat cracks) was prevalent (Fig. 13) as was oxide scale formation on the bristle (Fig. 14) with various color gradations noted. Integrity testing in bench and engine experiments demonstrated significant wear, tribological problems, and

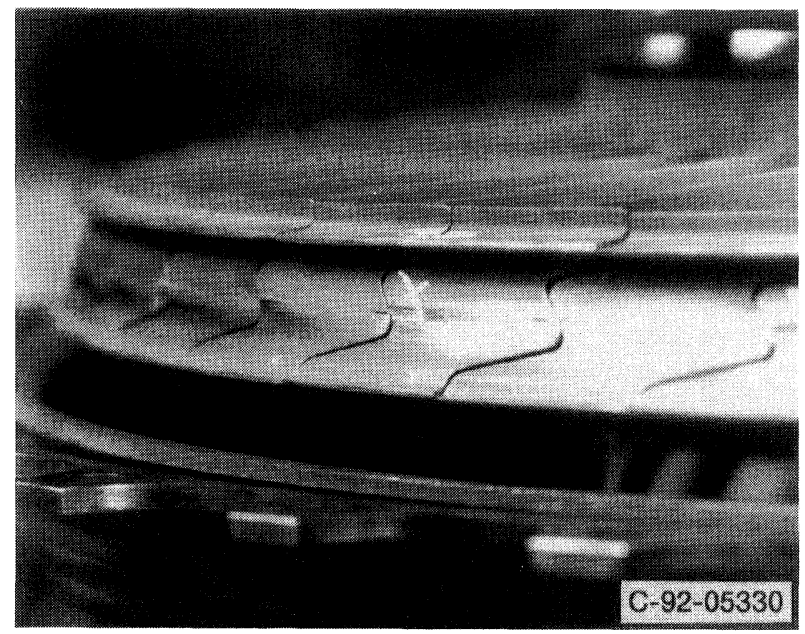

FIGURE 10 Fourth-stage turbine after testing, showing polishing of leading edges.

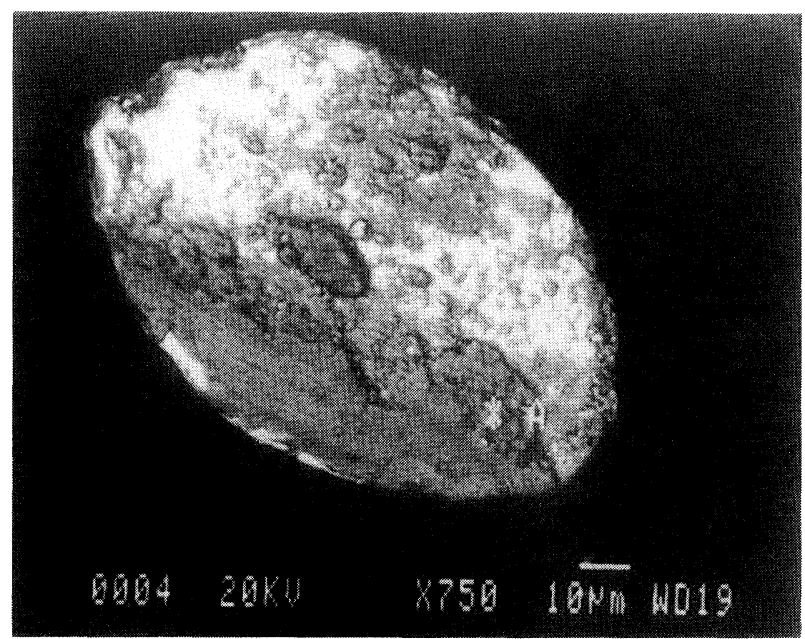

FIGURE 11 Posttest metallographic results for bristle tip from wear track.

short life, but no seal failures or engine failures due to seal malfunctions.

The dual-brush compressor discharge seal configuration and engine testing (Hendricks et al. [1994]) were designed to provide performance data for both the engine and the dual-brush and labyrinth seals (Figs. 4 and 5). The geometries of the seal, rub runner, and engine seal package were well defined. The nominally $0.13-\mathrm{mm}(0.005-$ in.) 8-rms, rub-runner coating was chromium carbide, a D-gun-sprayed mixture of $\mathrm{Cr}_{3} \mathrm{C}_{2}$ and $\mathrm{Cr}_{7} \mathrm{C}_{3}$ with a nickel chromium binder $[65(92 \mathrm{Cr}-8 \mathrm{C})+35(80 \mathrm{Ni}-20 \mathrm{Cr})]$. The bristles were Haynes 25 alloy. From testing experience, it 
was assumed that 40 percent of the pressure drop would occur across the first brush and 60-percent across the second brush, implying stiffer bristles and greater wear on the second brush. This anticipated result is shown in Figs. 15 and 16. Figure 15 illustrates the nominal rub surface wear; and Fig. 16, the wear associates with an assumed hard start or dynamic excursion. Further metallographic analysis of the brush bristle wear bands and the matrix material (Fig. 17) showed little or no evidence of material loss or transfer (Fig. 18). The bristle tips exhibited some shear smearing and evidence of some oxidation but were otherwise clean (Fig. 19).

\section{SUMMARY AND FUTURE NEEDS}

1. The integrity and performance of the brush seal have been established; its potential long-term advantages over the labyrinth seal have been demonstrated.

2. What is not understood is the nature of the interface, its tribological behavior, how heat is generated and rejected, the interbristle dynamics, and ultimately the life of the seal between changeouts.

3. It is important to develop a prediction tool

a. that details the flow and heat transfer within the bristle pack and at the rotor-bristle interface

b. that couples the fluid-structure interactions under thermomechanical loads, including rotor and bristle dynamics

c. that permits time-dependent calculations of tip loads and thermal fluid behavior

d. that has a rub model for bristle tip and rotor surface wear

e. that has a knowledge base including the tribological pairing of the interface material.

f. that supports conjugate heat transfer between bristles, interface, seal mounting flanges, and sealant fluid

g. that provides interaction between the power stream and the secondary air systems associated with seal leakages that control cooling, lubrication, and turbomachine dynamics

4. It is necessary to develop both rub-runner coatings and bristle materials as tribological pairs that will enable brush seals to operate to $815^{\circ} \mathrm{C}\left(1,500^{\circ} \mathrm{F}\right)$ ambient fluid temperature at surface speeds to $460 \mathrm{~m} / \mathrm{s}$
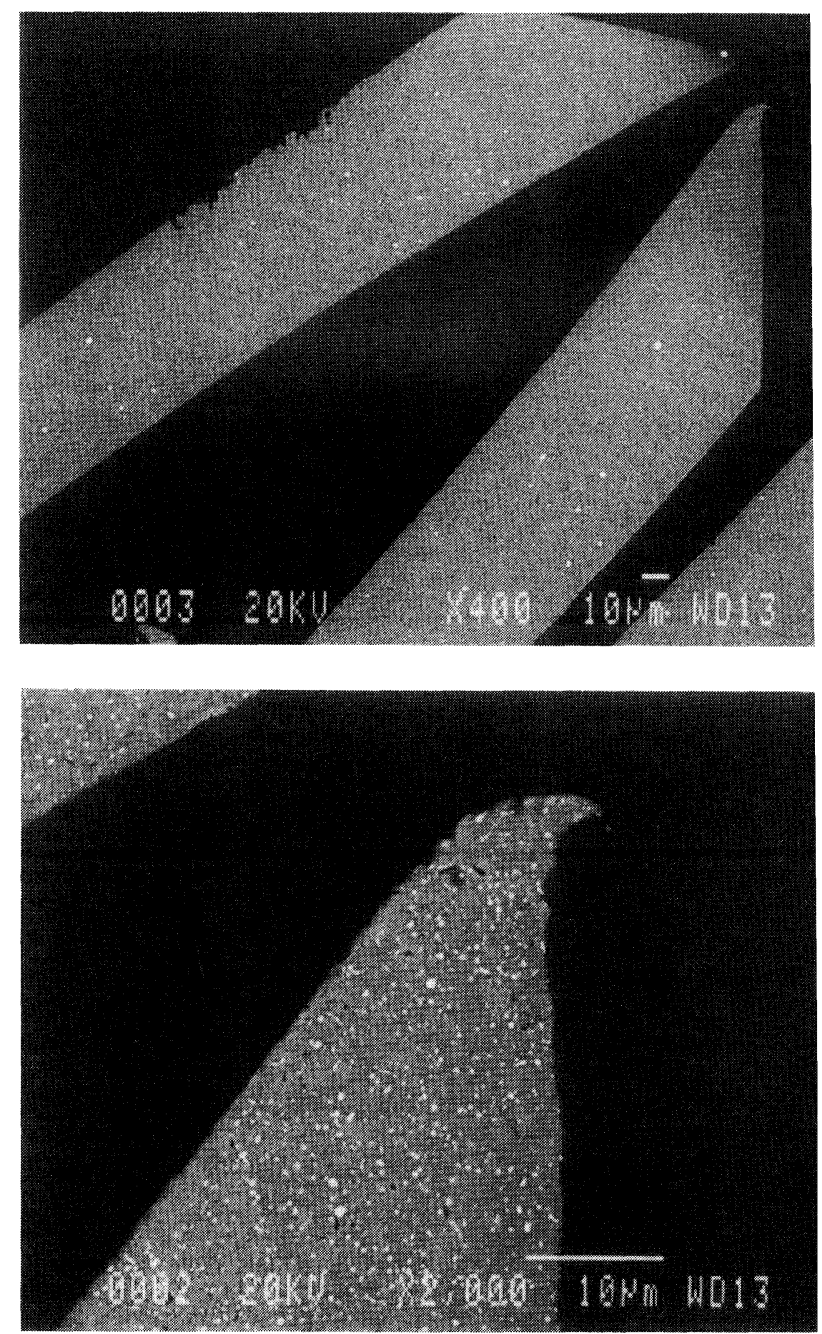

FIGURE 12 Posttest analysis of bristles cut from brush seal, showing irregular tips.

$(1,500 \mathrm{ft} / \mathrm{s})$ - with the next generation goal as $1,090^{\circ} \mathrm{C}$ $\left(2,000^{\circ} \mathrm{F}\right)$ at $500 \mathrm{~m} / \mathrm{s}(1,650 \mathrm{ft} / \mathrm{s})$. Such demanding operational environments will require both new materials and rethinking of brush designs, putting the prediction tool of item 3 in even greater demand.

\section{Acknowledgment}

The author gratefully acknowledges the help of Robert C. Bill and George A. Bobula and the U.S. Army Vehicle Propulsion Directorate.

\section{References}

Anon., 1993. Brushing Up on Technology. Directions, vol. 1, no. 2, p. 1, Pratt \& Whitney, East Hartford, CT. 

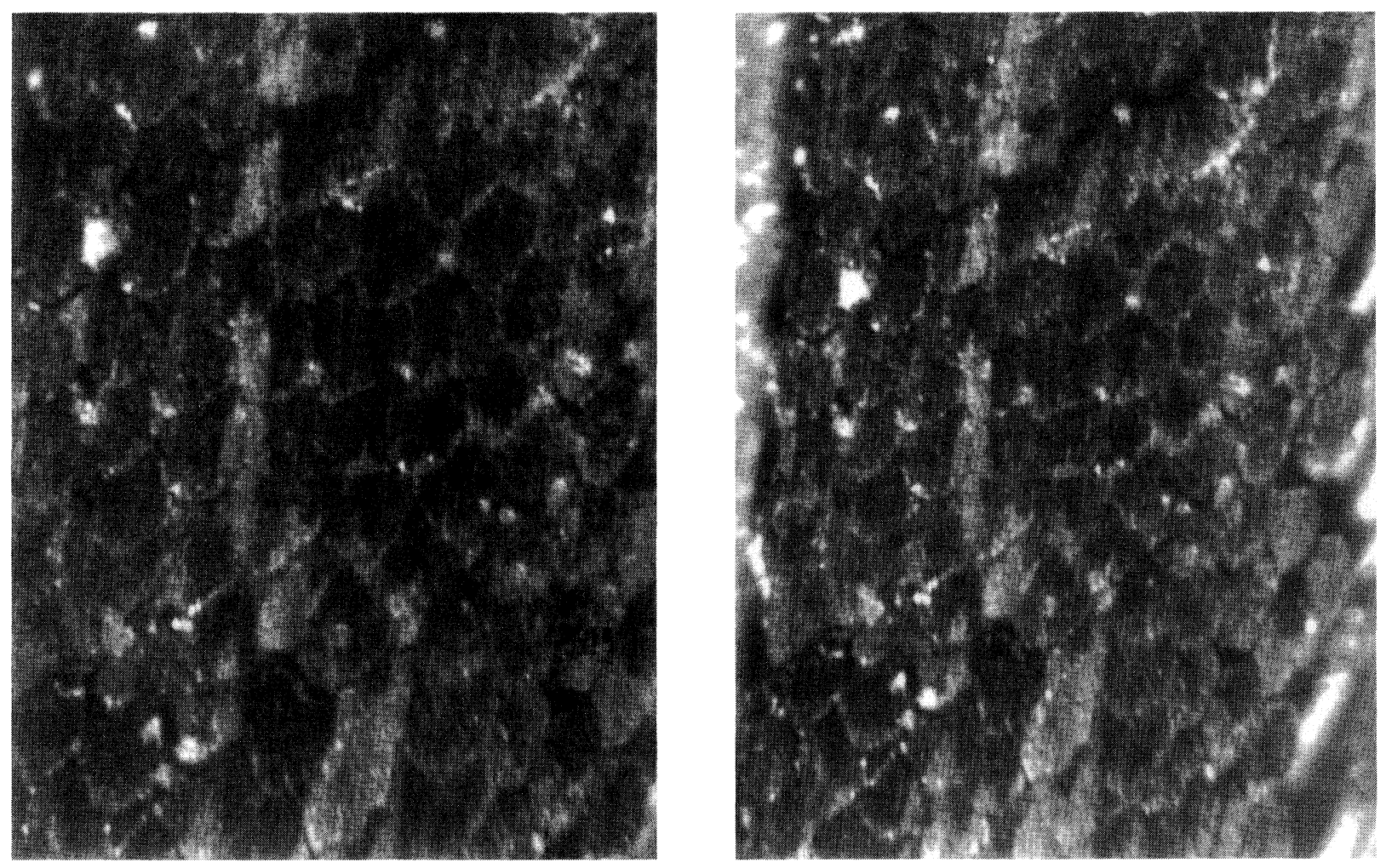

FIGURE 13 "Smearing" of bristle tips (T-700 test).
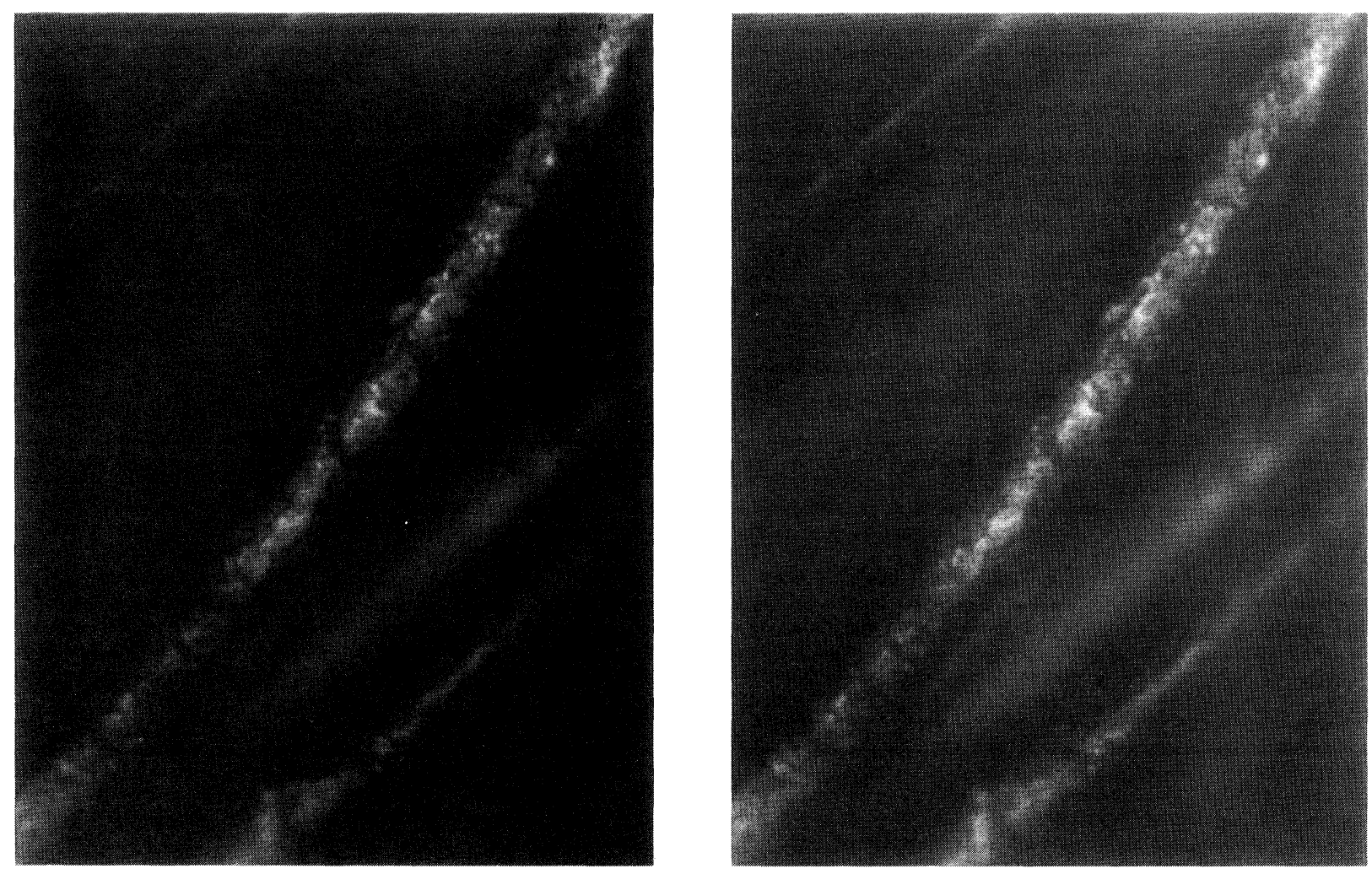

FIGURE 14 Oxide scale on bristles (T-700 test). 


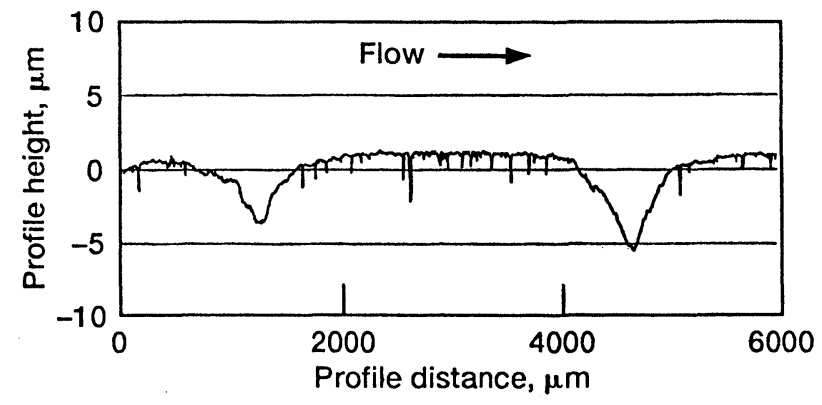

FIGURE 15 Compressor discharge seal profile showing slight wear scars.

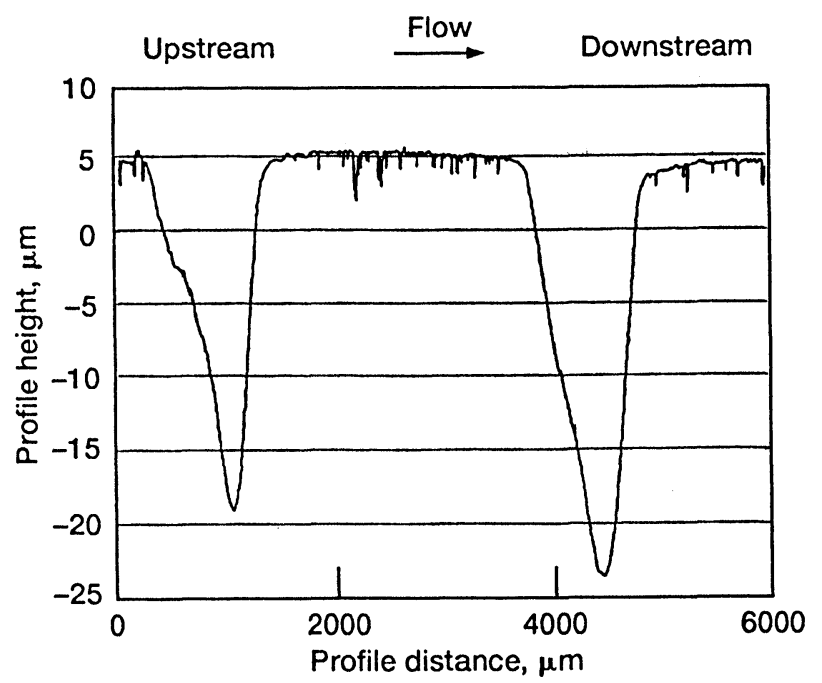

FIGURE 16 Compressor discharge seal profile showing deeper wear scars. a) Upstream (lower) wear band; b) Downstream (upper) wear band.

Anon., 1994. Pegasus Ready to Air-Launch from Stargazer, CPIA Bulletin, vol. 20, no. 1, p. 6.

Atkinson, E. and Bristol, B. L., 1992. Effects of Material Choices on Brush Seal Performance, Lubrication Engineering, vol. 48, no. 9, pp. 740-746.

Basu, P., Data, A., Derby, R., Johnson, R., Loewenthal, R., and Short, J., 1993. Brush Seal Design Guide. Report WL-TR-93-2029, Texas A\&M University, College Station, TX.

Braun, M., Canacci, V., and Hendricks, R., 1990. Flow Visualization and Motion Analysis for a Series of Four Sequential Brush Seals, AIAA Paper 90-2482.

Braun, M. J. and Kudriavtsev, V. V., 1993. A Numerical Simulation of a Brush Seal Section and Some Experimental Results, ASME Paper 93-GT-0398.

Carlile, J. A., Hendricks, R. C., and Yoder, D. A., 1992. Brush Seal Leakage Performance with Gaseous Working Fluids at Static and Low Ro-
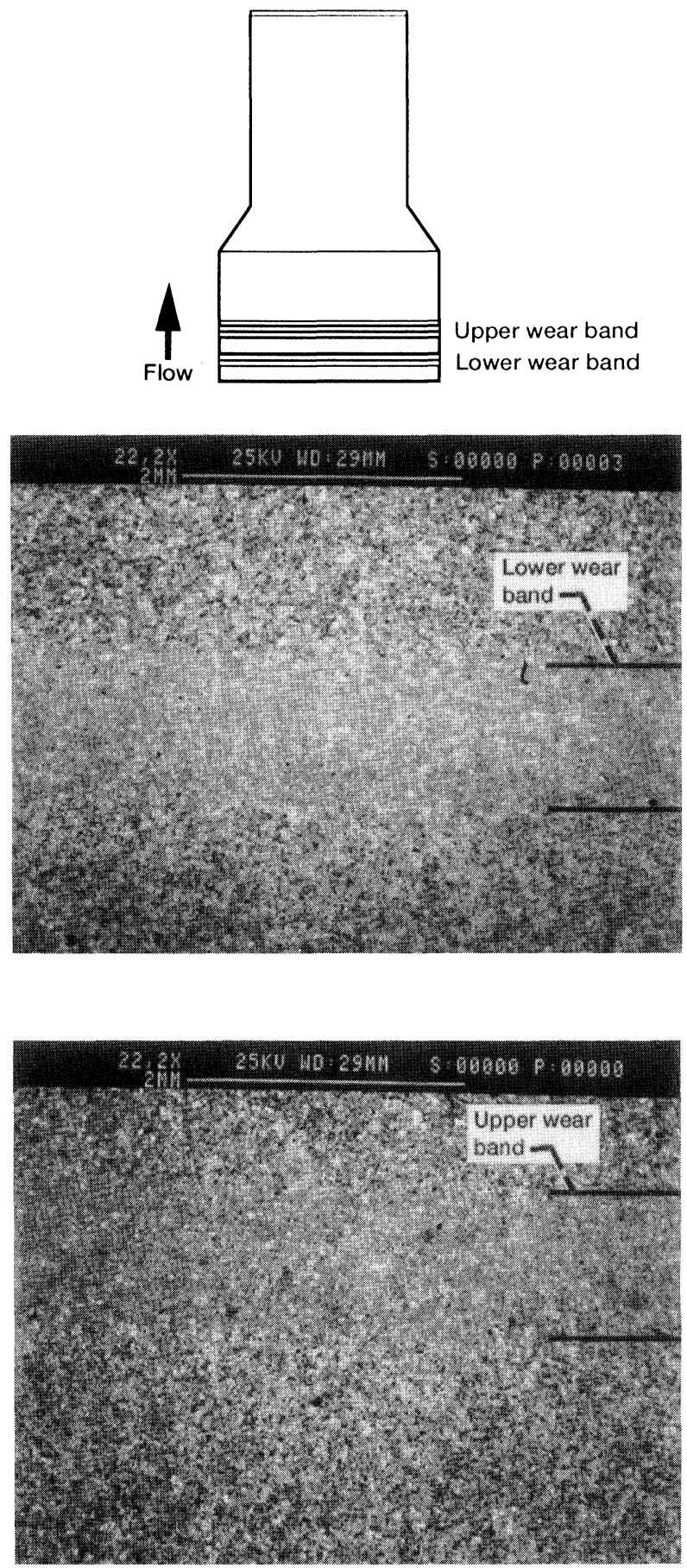

FIGURE 17 Compressor discharge seal rub-runner wear bands. a) Light area in coating matrix between bands; b) Light area in upstream (lower) wear band; c) Light area in downstream (upper) wear band. 

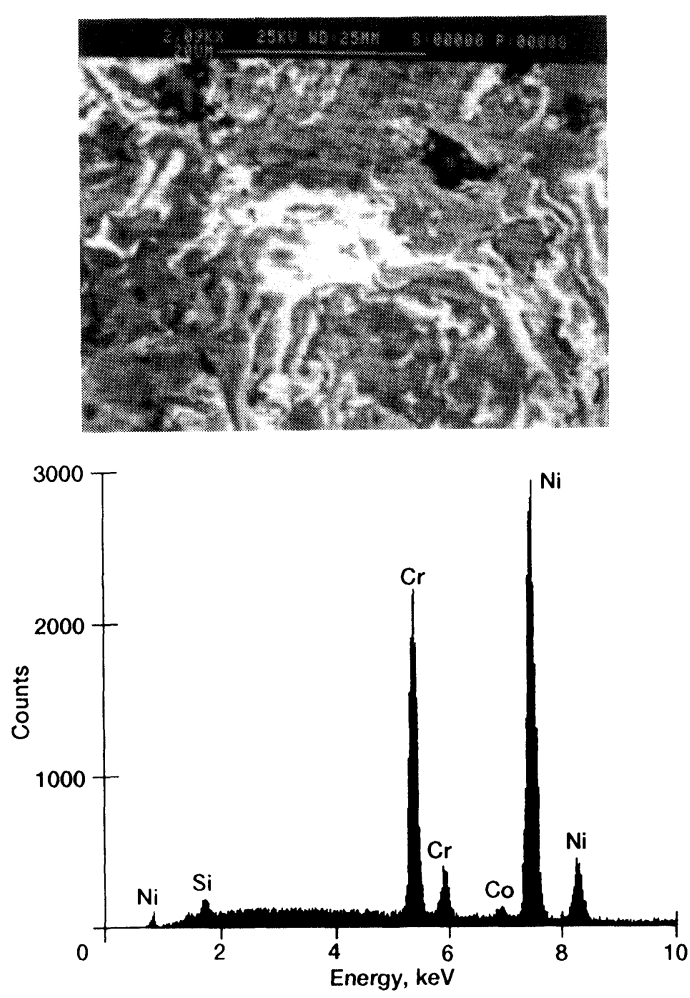

(a) Light area in coating matrix between bands.
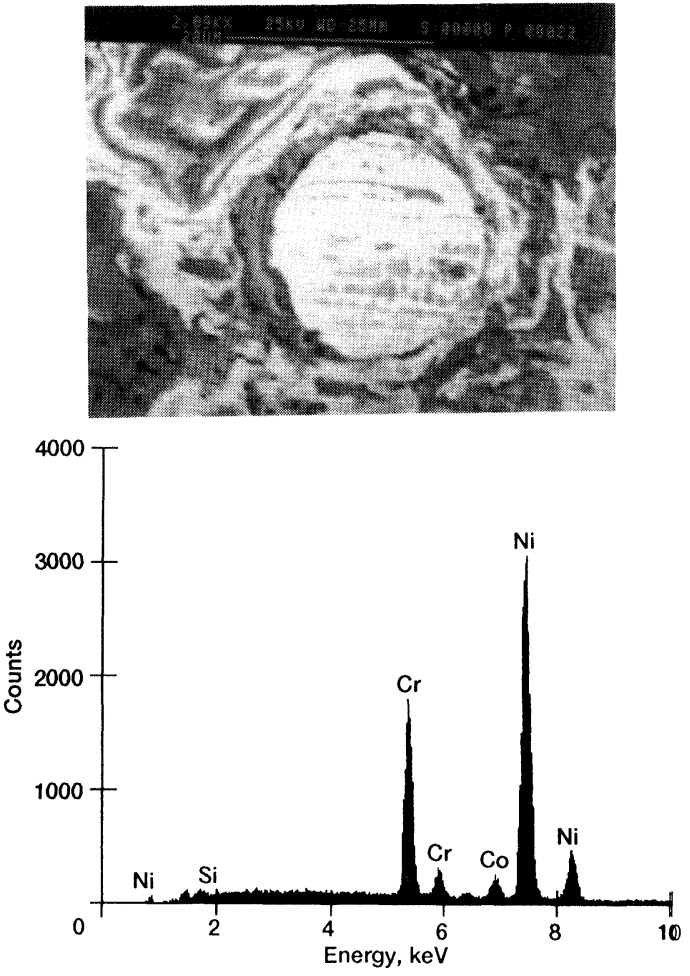

(b) Light area in upstream (lower) wear band.
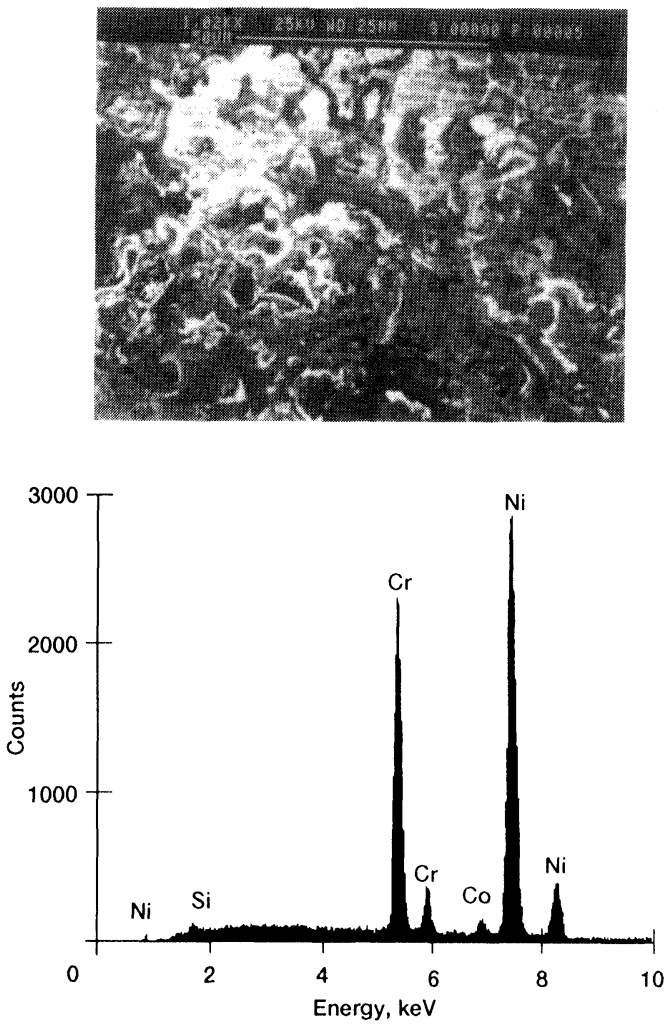

(c) Light area in downstream (upper) wear band.

FIGURE 18 SEM peaks associated with chromium-carbide-coated rub runner 

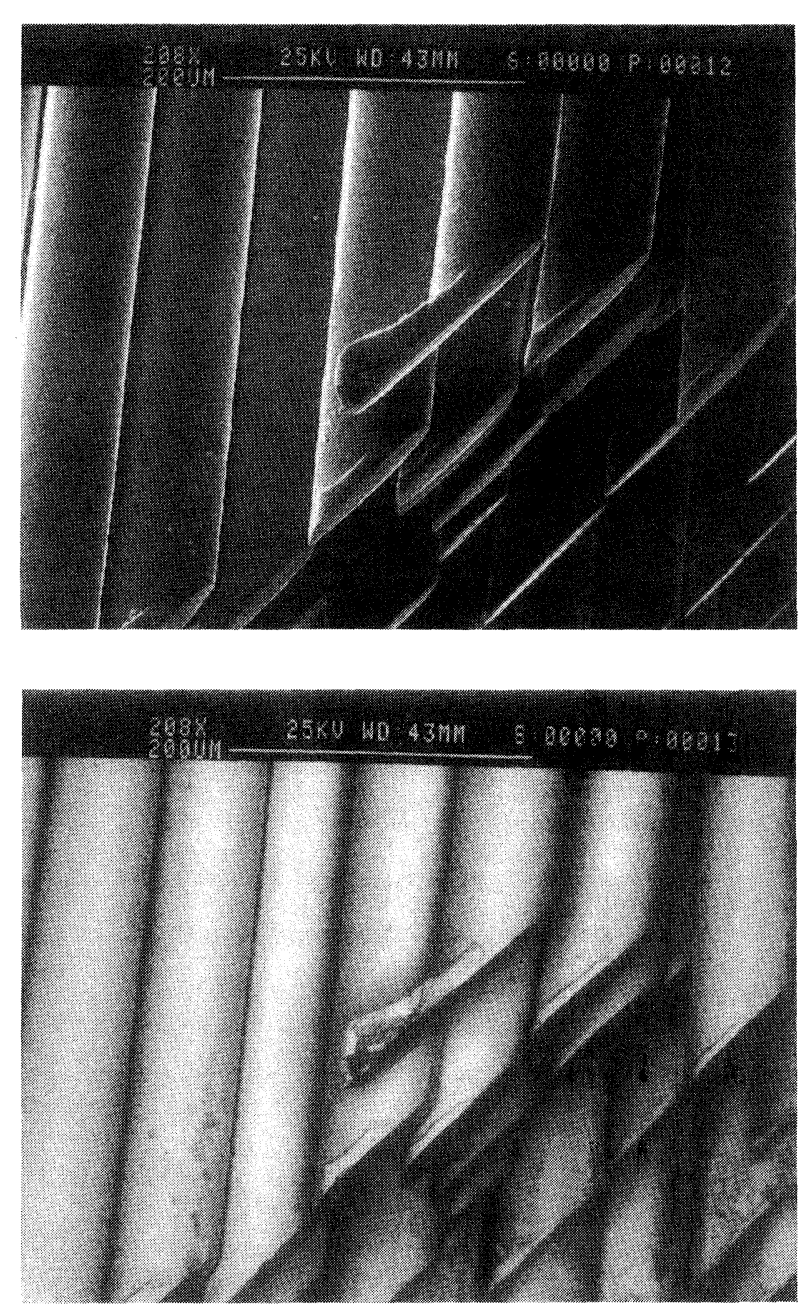

FIGURE 19 Closeup views of bristles (compressor discharge seal).

tor Speed Conditions, presented at the 37th International Gas Turbine and Aeroengine Congress and Exposition, sponsored by the American
Society of Mechanical Engineers, Cologne, Germany, June 1-4. (See also NASA TM-105400.)

Childs, D. W., Ramsey, C. J., and Pelletti, J. M., 1989. RotordynamicCoefficient Test Results for the SSME HPOTP Turbine Interstage Seal for the Current and Improved Swirl Brake, NASA Lewis Grant NAG3-181, Turbomachine Laboratories Report 338-TL-3-89, Texas A\&M University, College Station, TX.

Chupp, R. E. and Dowler, C. A., 1991. Performance Characteristics of Brush Seals for Limited Life Engines, ASME Paper 91-GT-281.

Chupp, R. E. and Nelson, P., 1990. Evaluation of Brush Seals for Limited Life Engines, AIAA Paper 90-2140.

Conner, K. J. and Childs, D. W., 1992. Rotordynamic and Leakage Characteristics of a 4-Stage Brush Seal, Report WL-TR-92-2125, Texas A\&M University, College Station, TX.

Derby, J., and England, R., 1992. Tribopair Evaluations of Brush Seal Applications, AIAA Paper 92-3715.

Ferguson, J. G., 1988. Brushes as High Performance Gas Turbine Seals, ASME Paper 88-GT-182.

Flower, R., 1990. Brush Seal Development System, AIAA Paper 90-2143. Hendricks, R. C. Schlumberger, S., Braun, M. J., Choy, F., and Mullen, R. L., 1991. A Bulk Flow Model of a Brush Seal System, ASME Paper 91-GT-325.

Hendricks, R. C., Carlile, J. A., Liang, A. D., Steinetz, B. M., Easter, B. T., Onstott, J. W., and Howe, H., 1992. Static Brush Seals for Propulsion System Interfaces, Advanced Earth-to-Orbit Propulsion Technology-1992, NASA CP-3174, vol. 1, pp. 432-439.

Hendricks, R. C., Carlile, J. A., and Liang, A. D., 1993a. Brush Seal Low Surface Speed Hard-Rub Characteristics, AIAA Paper 93-2534.

Hendricks, R. C., Griffin, T. A., Bobula, G. A., Bill, R. C., and Howe, H. W., 1993b. Integrity Testing of Brush Seal in Shroud Ring of T700 Engine, 38th ASME International Gas Turbine \& Aeroengine Congress \& Exposition, Cincinnati, $\mathrm{OH}$.

Hendricks, R. C., Griffin, T. A., Csavina, K. R., Pancholi, A., and Sood, D., 1994. Relative Performance Comparison Between Baseline Labyrinth and Dual-Brush Compressor Discharge Seals in a T-700 Engine Test, NASA TM-106360.

Holle, G. F. and Krishnan, M. R., 1990. Gas Turbine Brush Seal Applications, AIAA Paper 90-2142.

Stocker, H. L., Cox, D. M., and Holle, G. F., 1977. Aerodynamic Performance of Conventional and Advanced Design Labyrinth Seals with Solid Smooth, Abradable, and Honeycomb Lands-Gas Turbine Engines, NASA CR-135307.

Trutnovsky, K., 1977. Contactless Seals. Foundations and Applications of Flows through Slots and Labyrinths, NASA TT F 17352. 

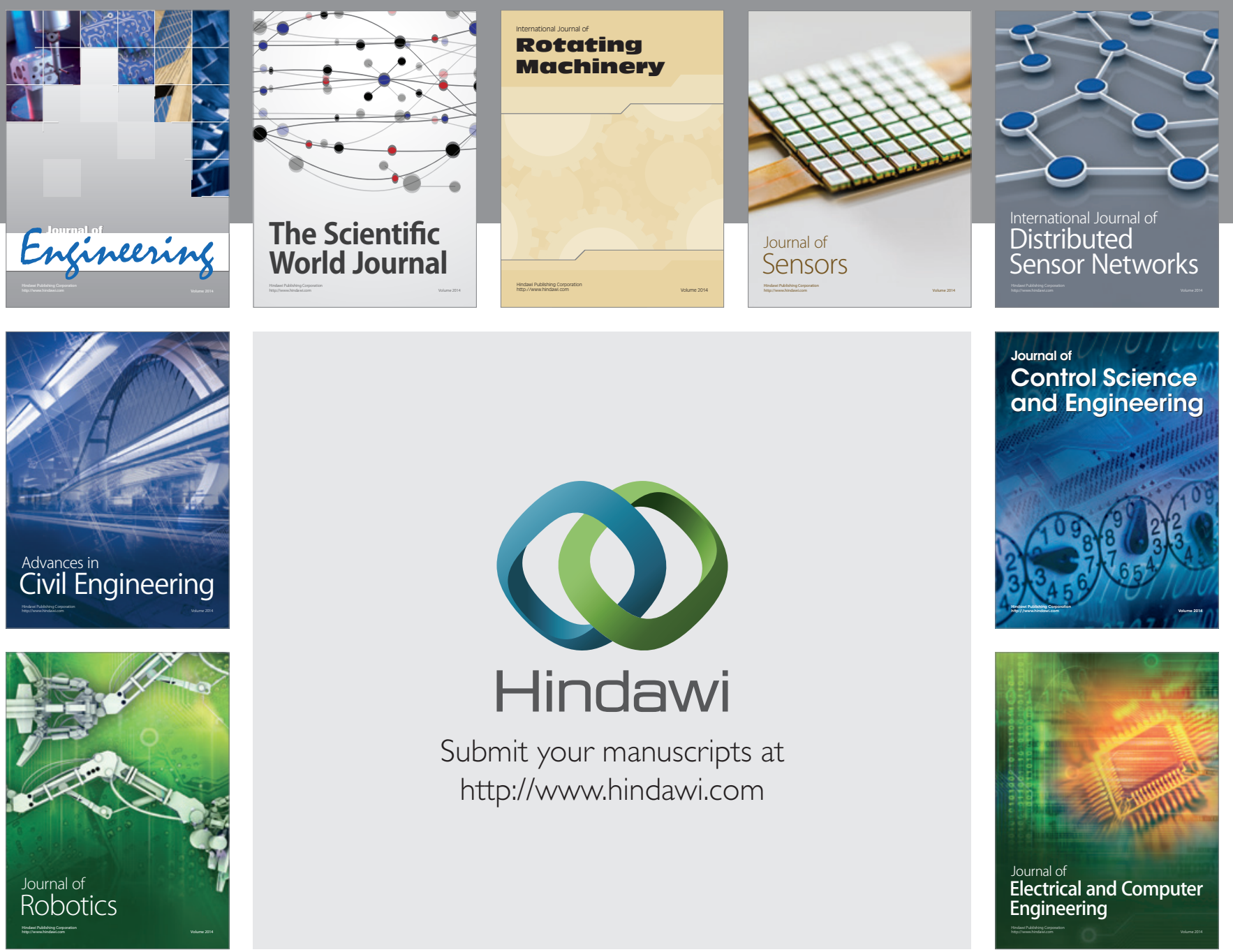

Submit your manuscripts at

http://www.hindawi.com
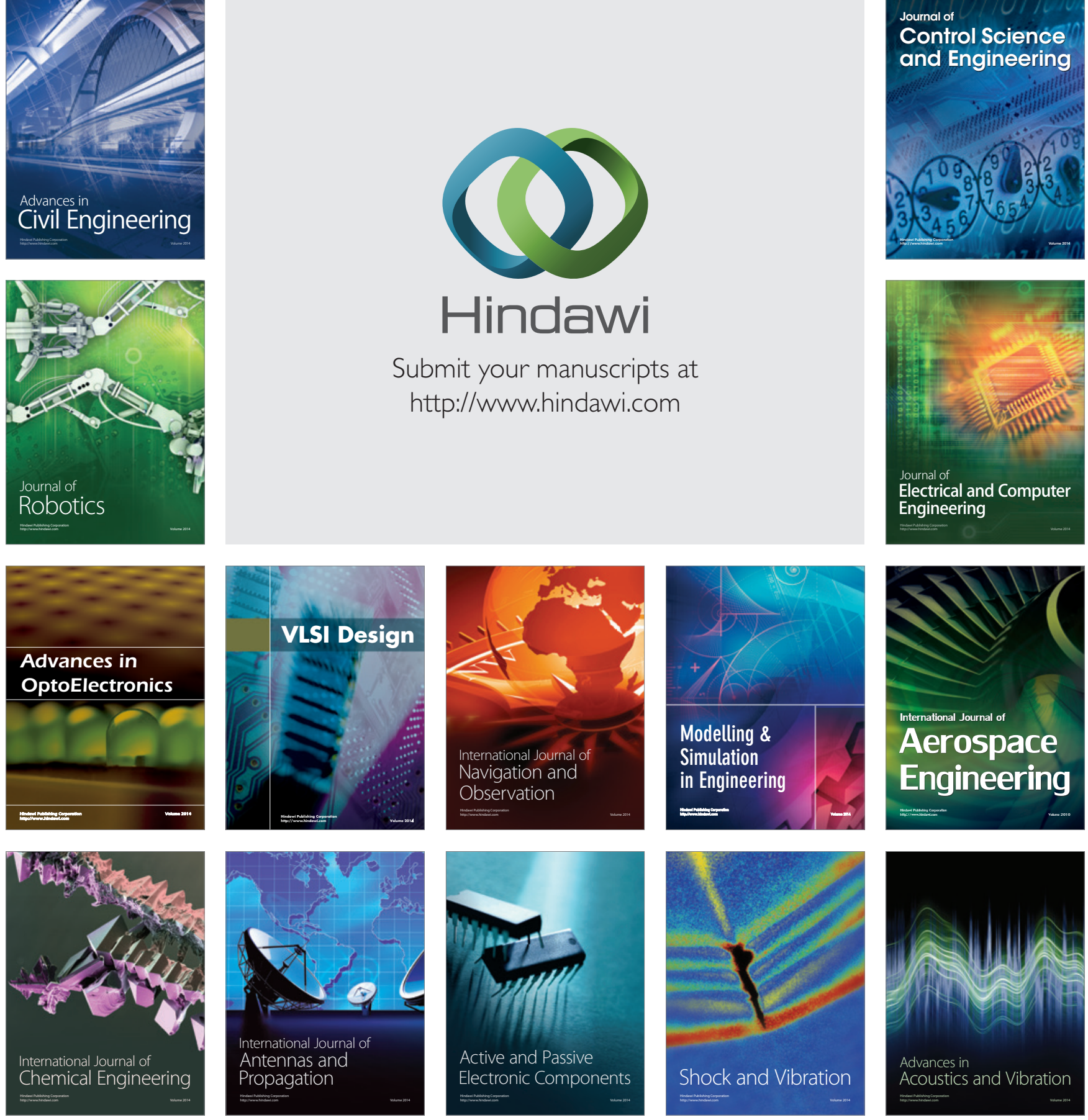